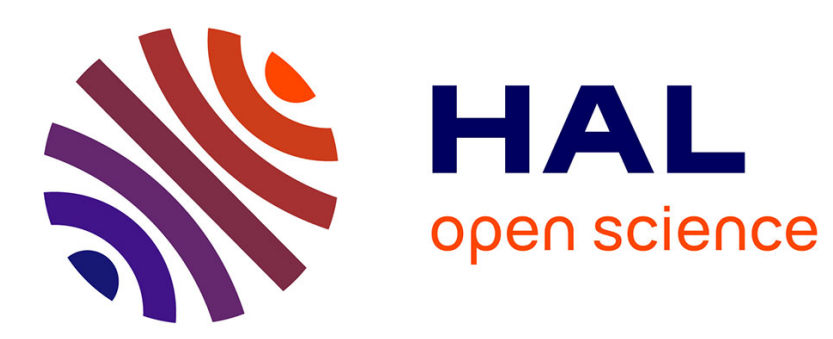

\title{
Discovering the anomalously cold Mediterranean winters during the Maunder minimum
}

\author{
Nazzareno Diodato, Gianni G. Bellocchi
}

\section{To cite this version:}

Nazzareno Diodato, Gianni G. Bellocchi. Discovering the anomalously cold Mediterranean winters during the Maunder minimum. The Holocene, 2012, 22, pp.589-596. 10.1177/0959683611427336 . hal-02646380

\section{HAL Id: hal-02646380 \\ https://hal.inrae.fr/hal-02646380}

Submitted on 29 May 2020

HAL is a multi-disciplinary open access archive for the deposit and dissemination of scientific research documents, whether they are published or not. The documents may come from teaching and research institutions in France or abroad, or from public or private research centers.
L'archive ouverte pluridisciplinaire HAL, est destinée au dépôt et à la diffusion de documents scientifiques de niveau recherche, publiés ou non, émanant des établissements d'enseignement et de recherche français ou étrangers, des laboratoires publics ou privés. 


\title{
Discovering the anomalously cold Mediterranean winters during the Maunder minimum
}

\author{
Nazzareno Diodato' and Gianni Bellocchi' ${ }^{1,2}$
}

\begin{abstract}
This work presents an attempt to reconstruct the Mediterranean Italy climate across one of the coldest interval (AD I645-I7I5) of the 'Little Ice Age' (LIA), characterized by a prolonged episode of low solar acitivty known as 'Maunder minimum' (MM). LIA was characterized by marked climatic variability over this part of southern Europe, particularly during the MM. Using a model based on adding subregional details to regional-scale reconstruction, we estimated for this period a mean winter temperature of $\sim 1^{\circ} \mathrm{C}$ lower than in the baseline period $196 \mathrm{I}-1990\left(\sim 8^{\circ} \mathrm{C}\right)$, and the anomaly further lowered down to about $-4^{\circ} \mathrm{C}$ in the winter of $1683-1684$. In addition, the interannual variability of extreme low temperatures makes the MM an outstanding climatic period. There is also some consistency of the empirical evidence with the modelling results that, for high-resolution wintertime seasonal reconstruction, central Mediterranean Sub-regional Area shows a colder climate than that represented by coarser simulation of European temperatures during the LIA period.
\end{abstract}

\section{Keywords}

documentary-proxy data, 'Little Ice Age', 'Maunder minimum', 'Mediterranean Sub-regional Area', temperature reconstruction, winter temperatures

\section{Introduction}

Data on past climate are a prerequisite for many studies of climate processes. Studying past climate change is the important approach to understand future changes, for a number of reasons outlined by Skinner (2008) and Nicholls (2010), e.g. providing a climate baseline against which to measure future climate changes, estimating the underlying 'natural' variability of the climate, and helping determine whether we are already causing the climate to change (for example, understanding the urban heat island and its possible effect on global warming estimate).

There is voluminous indirect evidence that climatic conditions in the past 500 years were often different from our contemporary experience (e.g. Grove, 1988; Lamb, 1982; Wanner et al., 2009). However, the nature of these differences, and what caused them, remains elusive (Bradley and Jones, 1992; Jones and Mann, 2004). Analyses of global mean temperature records suggest a detectable signal of solar influence on decadal to millennial timescales. Surface winds and surface ocean hydrography in the subpolar North Atlantic appear to have been influenced by variations in solar output through the entire Holocene, i.e. from around $10000 \mathrm{BC}$ to present day (Bond et al., 2001). However, geographical variations of this influence are poorly known but almost certainly do not consist of a uniform surface warming in response to increased solar activity (Haigh, 2003). Several chronologies extending over a long time span, with variability displaying a strong and direct association with changing local temperatures, have been utilized to help reconstruct hemispheric or global temperatures (Jansen et al., 2007). For Britain, a dataseries giving mean monthly temperatures for central England stretching back to 1659 was calculated by Gordon Manley in the 1970s (Manley, 1974). This is the longest standardised instrumental record available for anywhere in the world, which includes several decades of warming associated with the end of the LIA.
Reliable seasonal temperature reconstructions are not available for Mediterranean areas. In this respect, it is of interest to detect if, and with what frequency, the Southern Europe regions have experienced cold winters during the 'Little Ice Age' (LIA, AD 1300-1850). This issue puts forward unexpected results, especially in the temperature ranges (Bhatnagar et al., 2002). In fact, whether the chronological limits of the LIA are well known over large geographical areas in the Northern Hemisphere, the same studies suggest that the LIA was neither a spatially nor a temporally coherent climatic event (e.g. Bradley and Jones, 1992; Diodato, 2007; Grove, 2001; Ogilvie and Jónsson, 2001). The years $1675-1715$ coincided with a period of reduced solar activity (along with high volcanic activity) known as 'Maunder minimum' (Eddy, 1976, indicated as MM), which was probably also the coldest period in some European areas, with extended Alpine glaciers, and frequent winter freezing events in The Netherlands and in England (Jones and Mann, 2004). Even if they are not necessarily indicative of a cold climate, the effects of these winters are well represented in historical paintings, e.g. in 'Winter landscape with skaters' by Hendrick Avercamp, collection of the

'MetEROBS - Met European Research Observatory, GEWEX-CEOP Network, World Climate Research Programme, Italy

${ }^{2}$ Grassland Ecosystem Research Unit, French National Institute of Agricultural Research, France

Received I2 April 201 I; revised manuscript accepted I4 September 20II

\section{Corresponding author:}

Gianni Bellocchi, Grassland Ecosystem Research Unit, French National Institute of Agricultural Research, 234 avenue du Brézet, 63000 Clermont-Ferrand, France.

Email: giannibellocchi@yahoo.com; gianni.bellocchi@clermont.inra.fr 


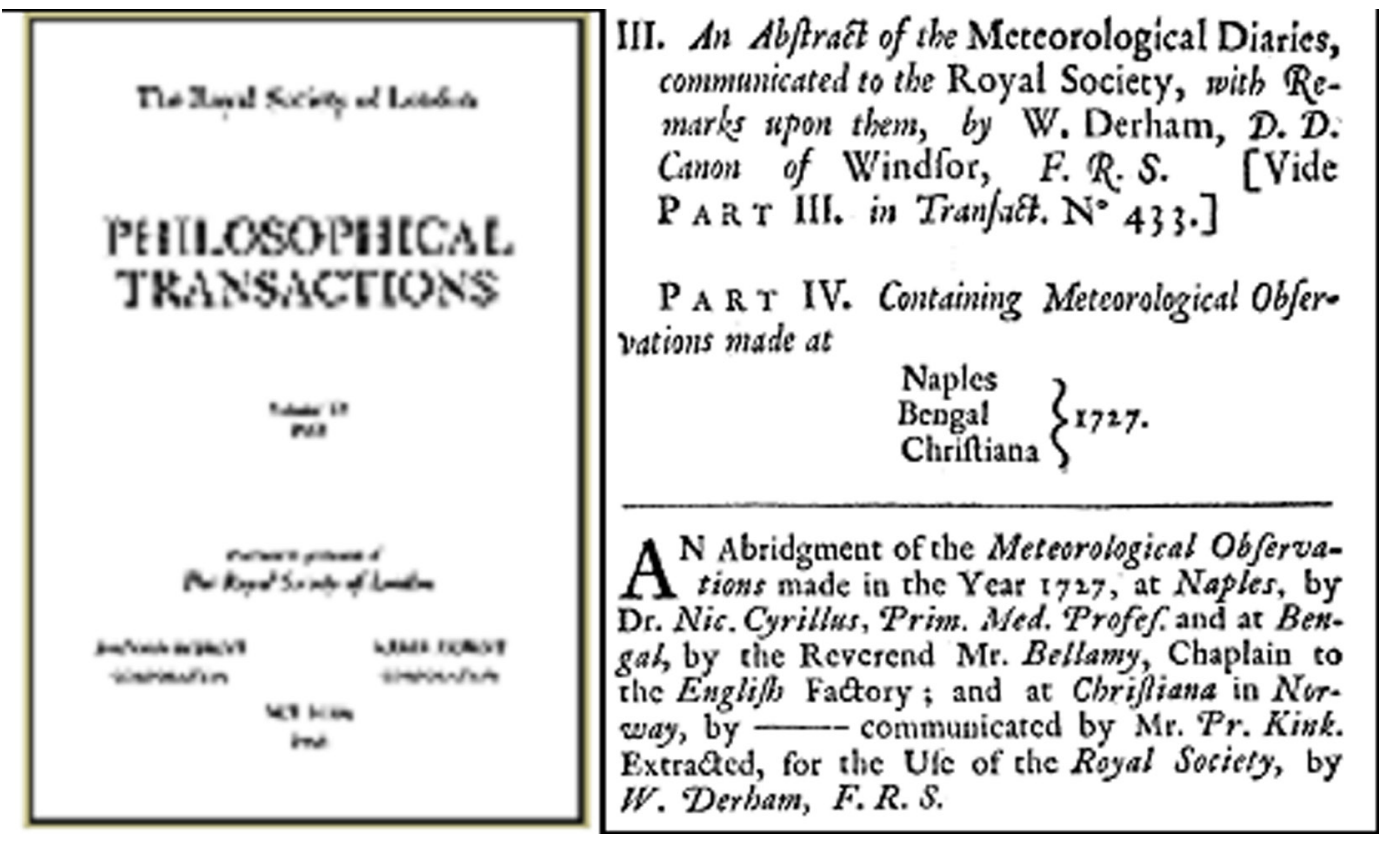

Figure I. Cover page of Philosophical Transactions and excerpt from the Meteorological Diaries, communicated to the Royal Society of London, about the beginning of instrumental weather observations in the Kingdom of Naples (Derham, 1733-1734)

Rijksmuseum Amsterdam, http://www.rijksmuseum.nl) illustrating Amsterdam under a frozen blanket yet in 1608 (just before the MM). During and after the MM, also the River Thames in London froze many times, the ice was thick and lasted long enough for festivals to be held on the river, as in 1663, 1677 (e.g. 'The frozen Thames River' by Abraham Hondius, collection of the Museum of London, http://www.museumoflondon.org.uk), 1684, 16941695, 1708-1709, and 1740 (Fagan, 2001).

In Italy, the earliest temperature readings were made at Pisa $\left(43^{\circ} 43^{\prime}\right.$ North, $10^{\circ} 24^{\prime}$ East) over the years $1657-1658$ by Vincenzo Viviani and Giovanni Alfonso Borelli, and at Modena (4439' North, $10^{\circ} 56^{\prime}$ East) during the year 1694 by Bernardino Ramazzini (Camuffo et al., 2010b). For southern Italy, however, temperature records are more limited since the first instrumental observations started in the Kingdom of Naples as early as 1727 thanks to Domenico Cirillo, as documented by the Meteorological Diaries of the Royal Society of London (Figure 1).

Tree-ring sites were used by Brewer et al. (2007) to support the reconstruction of historical climate in the Mediterranean during the last 500 years. However, more recent works (e.g. Loehle, 2009; Visser et al., 2010) pointed out instabilities in tree-ring proxy calibration in a number of forests at high northern latitudes and Alpine locations, which demands caution in temperature reconstruction by tree-ring measurements.

Documentary-proxy data can be suitable for detection of climate variability. However, collection and validation of long documentary series can be time-consuming. As a matter of fact, continuous reconstruction of temperatures from documentary sources has not yet been done for this region. The temperature reconstruction from instrumental series recently addressed by Camuffo et al. (2010a) for Italy does not date back to before 1790 for central and southern Italian regions. This is why in this study we have reconstructed high-resolution winter temperatures in an area covering southern and central Italy and named central 'Mediterranean Sub-regional Area' (MSA), based on large-scale variables and documentary-proxy data. In particular, the mixed-regression model developed by Diodato et al. (2010) was used for winter temperature reconstruction during the MM. The case of 1683-1684 was examined with more detail because temperatures were extraordinarily cold over much of Europe that winter.

\section{Methods}

\section{Winter temperature data}

The study is based on a set of both monthly modelled regional temperatures and documentary proxy data at a typical Mediterranean area of central and southern Italy (MSA in Figure 2). The study area extends over $\sim 90000 \mathrm{~km}^{2}$, approximated by a bounding box whose lower left corner is at $36.8^{\circ}$ North and $13.6^{\circ}$ East; and whose upper right corner is at $41.9^{\circ}$ North and $18.8^{\circ}$ East.

Temperature data (hereafter called $T_{\mathrm{R}}$ ) were derived from Luterbacher et al. (2004) for Europe over 1500-2002. This largescale, homogeneous European data set from historical instrumental series and multiproxy data, upscaled at $0.5^{\circ}$ grid resolution (http://www.ncdc.noaa.gov/cgi-bin/paleo/eurotemp.pl) was used to extract the regional component of winter temperature for the study area in the years 1675-1715. We have chosen a winter period, which is defined as the three-month period from December until February. This reconstruction was done with most predictors originating from central and northern Europe. This is why, for southern Europe, we have used documentary-proxy data derived from two main sources to complement these data: Moio and Susanna Manuscript (Ferrari, 1977), and Corradi's Annals (Corradi, 1972). The Corradi's Annals report on the climatological extremes (and resulting environmental impacts) occurred in Italy from 5 to 1850 AC. The chronicles of Giovanni Battista Moio and Gregorio Susanna, publised by Ferrari (1977), report on climate extremes and famines for Calabrian region, and also include weather information dating from the sixteenth to the eighteenth century. These pre-instrumental sources were systematically used to evaluate occurrence, duration and geographical location of extreme climatic events. A data bank (Catalogue EVA - Environmental Events of the ENEA - Italian National Agency for New Technologies, Energy and the Environment, Clemente and Margottini, 1991) was also referred to and used when necessary. Breaks in the chronological records (Figure 3a) are evidence for some typical discontinuities of documented events and the required compensation for the synoptic analysis of different sources. These sources report records of meteorological and environmental observations for hundreds of sites, with an imprecise extension depending on the area and the period (that makes it difficult to display their whereabouts). The manuscript texts usually focus on the 


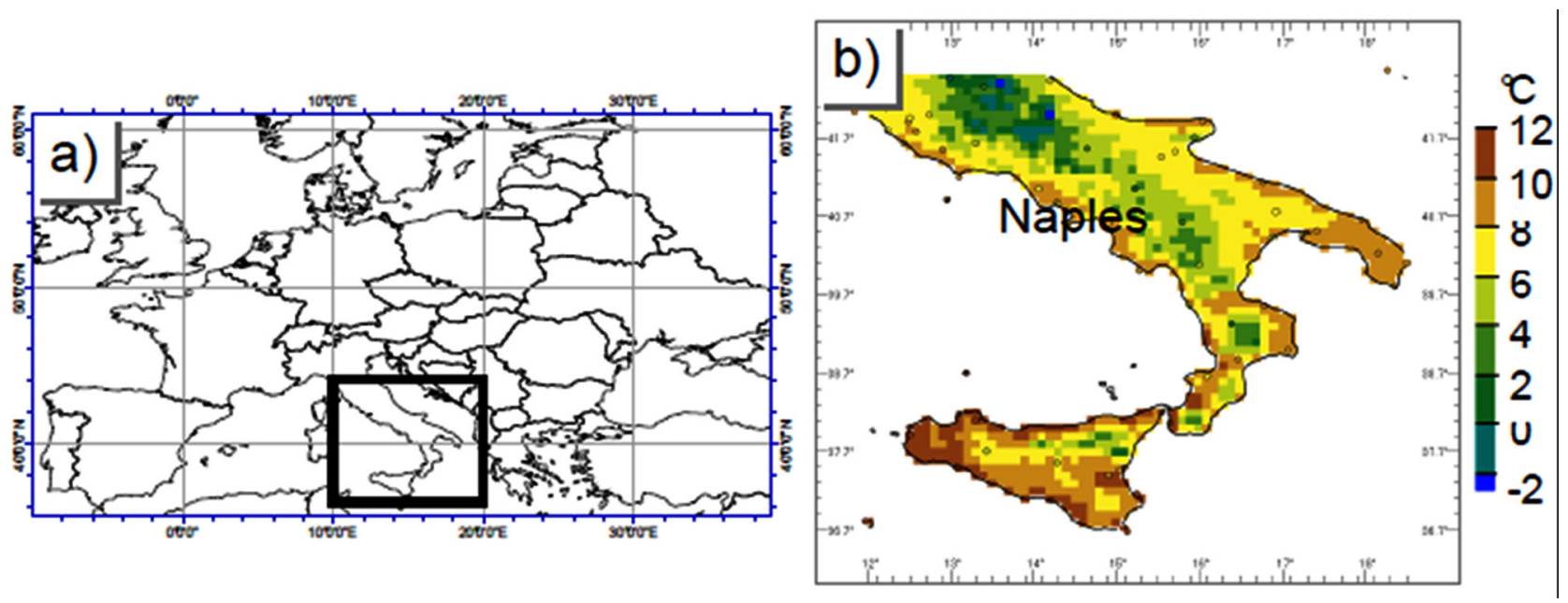

Figure 2. (a) Geographical setting of the Mediterranean Sub-regional Area (MSA, squared). (b) Winter temperature pattern averaged over I96I-1990 in the MSA, as arranged by LocClim FAO software at $10 \mathrm{~km}$ resolution (http://www.fao.org/sd/2002/ENI203a_en.htm)

a)

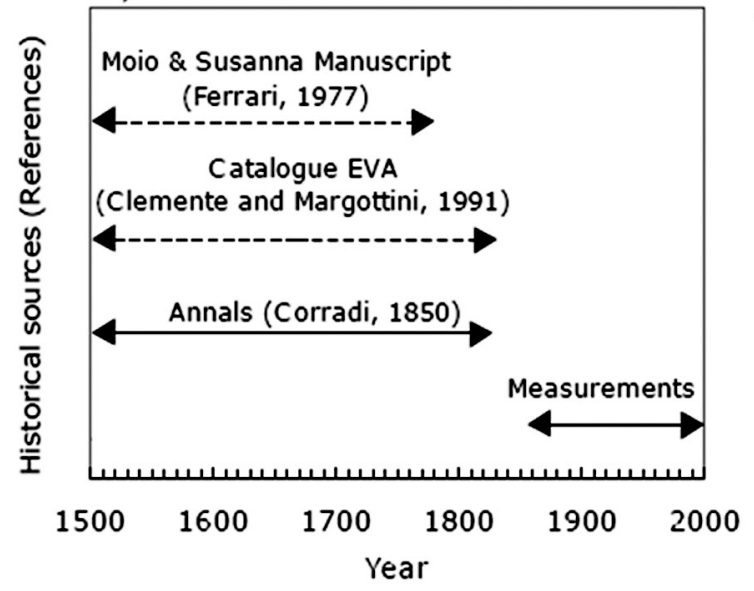

b) Winter D J F M AM J J A SON ETASIW Sources

$1 .$.
1675
1676
1677
1678
1679
1680
1681
1682
1683
1684
1685
$\ldots$

$\begin{array}{llllllllllll}1 & -1 & 0 & 0 & 0 & 0 & 0 & -1 & -1 & 0 & 0 & 0\end{array}$ $\begin{array}{llllllllllll}0 & 0 & 0 & 0 & 0 & 0 & 0 & 0 & 0 & 0 & 0 & 0\end{array}$ $\begin{array}{cccccccccccc}-1 & -1 & -2 & 0 & 0 & 0 & 0 & 0 & 0 & 0 & 0 & 0\end{array}$ $\begin{array}{llllllllllll}0 & 0 & 0 & 0 & 0 & 0 & 0 & 0 & 0 & 0 & 0 & 0\end{array}$ $\begin{array}{llllllllllll}0 & -1 & -1 & -1 & 0 & 0 & 0 & 0 & 0 & 0 & 0 & 0\end{array}$ $\begin{array}{llllllllllll}0 & -1 & -1 & 0 & -1 & 0 & -1 & -1 & -1 & 0 & 2 & 0\end{array}$ $\begin{array}{llllllllllll}1 & -2 & 0 & 0 & 0 & 0 & 0 & -1 & 0 & 0 & 0 & 0\end{array}$ $\begin{array}{llllllllllll}-1 & -1 & 0 & 0 & 0 & 0 & 0 & 0 & 0 & 0 & 0 & 0\end{array}$ $\begin{array}{llllllllllll}0 & 0 & 0 & 0 & 0 & 0 & 0 & 0 & 1 & 0 & 0 & 0\end{array}$ $\begin{array}{llllllllllll}-4 & -4 & -4 & -1 & 0 & 0 & 0 & 0 & 0 & 0 & 0 & 0\end{array}$ $\begin{array}{llllllllllll}0 & 0 & 0 & 0 & 0 & 0 & 0 & 0 & 0 & 0 & 0 & 0\end{array}$

\section{0}

0

$-4$

0

$-2$

$-2$

$-1$

$-2$

0

$-12$

0

(M) (A)

(M) (A)

(M) $(A)$

(M) (A)

(M) (A)

(M) (A)

(M) (A)

(M) (A)

(M) (A) (EVA)

(M) (A) (EVA)

(M) (A) (EVA)

Figure 3. (a) Chronological time span of historical sources used for meteorological collection (solid and dashed arrows represent continuous and discontinuous temporal data sources, respectively). (b) Coded temperature events over the first decade of the Maunder minimum (monthly indices are reported together with the winter sum, $\left.\Sigma T A S I_{w}\right)$; the months are contained in each meteorological season (D, December; J, January; F, February), e.g.Winter of I675 = D of I674 + J and F of I675. Sources: (M), Moio \& Susanna Manuscript; (A), Corradi Annals's; (EVA), Catalogue EVA

consequences of extreme meteorological phenomena, although it is possible to gauge, and even to quantify accurately, their intensity and particular characteristics. The damages caused are described in detail and the institutions involved often provided an estimate of the economic cost of any repairs or rebuilding work necessary. The impacts on the environment and population depended on various factors and it is not always easy to compare the severity of the climatic conditions, unless they were associated with specific effects.

Based on the above sources, monthly indices were calculated to preserve the variability described by the written sources similar to the long-period natural variability (Brázdil et al., 2005). These indices refer to anomaly classes taking into account temporal shifts between proxy and actual anomalies in different seasons of the year. The construction of monthly temperature values from documentary proxy data are detailed in Diodato et al. (2010) for winter and summer seasons. In particular for winter (December to February), temperature anomalies were coded by means of a monthly based Temperature Anomaly Scaled Index $\left(T A S I_{W}\right)$ as follows: -4 , freezing; -2 , very cold; -1 , cold; 0 , normal; 1 , warm; 2 , very warm. Seasonal values $\left(\Sigma T A S I_{W}\right)$ are computed as sum of monthly terms. Abrupt jumps from 'very cold' $(-2)$ to 'freezing' $(-4)$ in winter are due to the lack of appreciative intermediate states during the period used to calibrate the model (Diodato et al., 2010). This kind of understanding is offered in the form of an exemplary table layout (Figure 3b), incorporating monthly and seasonal values, and the relative sources for the period 1675-1684.

\section{Statistical downscaling of winter temperatures}

Local weather conditions inferred by proxy-indices can provide accurate estimates when mixed-regression models are used for downscaling regional temperature information. In the present approach, winter temperatures $\left(T_{\text {win }}\right)$ were reconstructed for the MSA for the Maunder minimum (1675 to 1715) assuming that the actual temperature values change simultaneously with the variation of two variables (regional temperature estimate and local temperature anomalies), by means of multiscale-adaptive 
a)

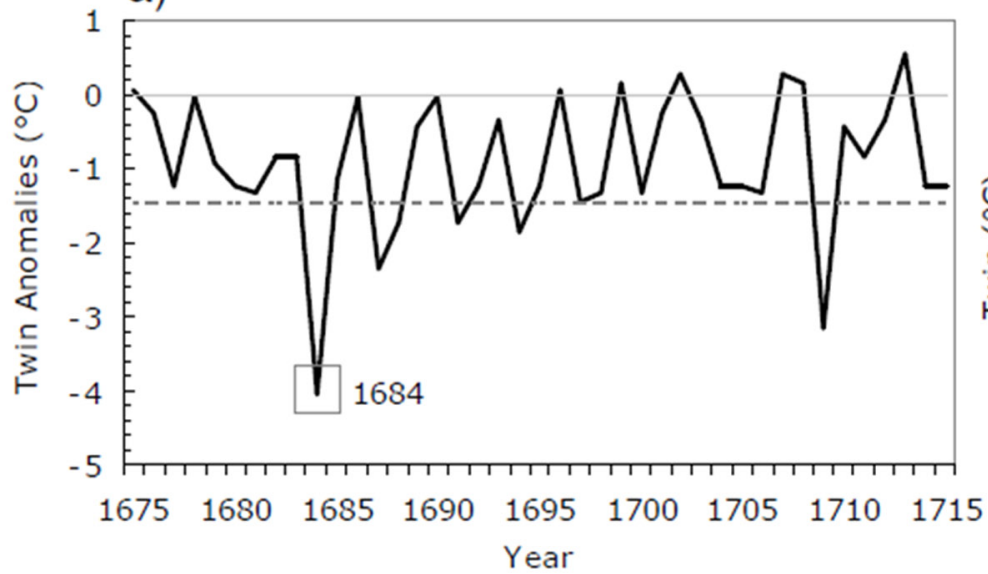

b)

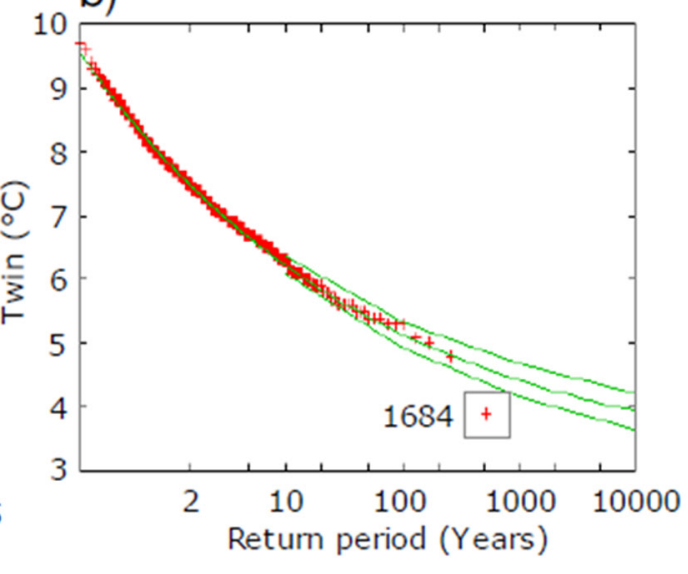

Figure 4. (a) Reconstructed winter temperature (Twin) anomalies over the Maunder minimum (bold line) relative to I96I-I990 mean (horizontal grey line), and two negative standard deviations (dashed grey line). (b) Gumbel plot of winter mean temperatures (reconstructed and observed) for the period I50I-2010, and the 0.95 probability confidence interval, based on the generalized Pareto distribution by the web-based Climate Explorer of the Royal Netherlands Meteorological Institute (van Oldenborgh and Burgers, 2005). One data point (I684) is spotted on both graphs as a case where the winter was extraordinarily severe

temperature regression (MTR) model that takes the following form (after Diodato et al., 2010):

$$
y\left(T_{\mathrm{MTR}}\right)=k \cdot \sqrt{T_{\mathrm{R}}}+\beta \cdot\left(11+\Omega_{S}+\Sigma T A S I_{\mathrm{W}}\right)
$$

The first term, $y\left(T_{\mathrm{MTR}}\right)$, is the subregional mean winter temperature output $\left({ }^{\circ} \mathrm{C}\right)$ of the (MTR) model; $T_{\mathrm{R}}$ is the regional component of mean temperature $\left({ }^{\circ} \mathrm{C}\right)$, as supplied by Luterbacher et al. (2004) and which drives the general temperature trend; $\Sigma T A S I_{\mathrm{W}}$ (sum of monthly values for winter of the Temperature Anomaly Scaled Index defined above) is the corresponding winter temperature subregional component, which meets areaspecific temperatures. Temperature conditions of the study area (Figure 2b) mark the validity domain of the model, approached in Eq. (1), for subregional estimations of mean winter temperature (positive values over a relatively limited range). Using an iterative calibration procedure (Diodato et al., 2010), coefficients of Eq. (1) were estimated over 68 years both including cold (1867-1903) and warm (1972-2002) intervals. It also ensured to simulate air temperature on periods with either more accurate (as in recent times) or less accurate data (as in historical times) from the MSA. A scale parameter $\left(\beta=0.268^{\circ} \mathrm{C}\right)$, together with the square root of $T_{\mathrm{R}}$, defines the magnitude of the process used to downscale the (MTR) model to the subregional scale. A shift parameter $\left(\Omega_{S}=11\right.$, unitless $)$ represents climatological boundary conditions, whereas $\Sigma T A S I_{\mathrm{W}}$ is the meteorological anomaly term. A scale parameter, $k\left({ }^{\circ} \mathrm{C}^{2}\right)$, was set equal to 1 to assure dimensional consistency.

The study by Diodato et al. (2010) makes Eq. (1) suitable to reconstruct past seasonal temperatures over Mediterranean Italy. The modelled response agreed well with an independent data set used for validation, indicating limited uncertainty (e.g. NashSutcliffe efficiency coefficient $>0.6$ ). This multiscale regressive model also allowed for overcomimg the loss of variance observed in the regional reconstruction. In the temperature series supplied by Luterbacher et al. (2004), standard deviation (sd) increases in more recent years, i.e. after the LIA ( $\mathrm{sd}=0.96$ against 0.74 for 1739-1783). This contrasts with the instrumental observations recorded by Domenico Cirillo in the eighteenth century ( $\mathrm{sd}=1.1$ ). The reconstructed series based on Eq. (1) give sd values around 1.0 for both recent and historical times.

\section{Results and discussion}

\section{Reconstruction of winter temperatures during Maunder minimum (MM)}

A first view of Twin time-pattern is proposed in Figure 4a, where temperature anomalies are shown relative to the 1961 to 1990 mean. Year-to-year winter temperature variability reflects the Mediterranean extreme cold and repeated seasons of snow occurred in 16 out of 25 winters between 1675 and 1700 (Beniston, 1994). In particular, in the years $1665,1677,1684,1687$ and 1692 , temperatures were extremely low with frozen rivers in peninsular Italy (Corradi, 1972; Lattanzi, 2000). Camuffo and Enzi (1994) mention numerous floodings in northern Italy between 1682 and 1707, very cold winters between 1684 and 1694 and a particularly cold winter in 1709 . Venetian Lagoon was also frozen in 1684 and 1709 (Camuffo, 1987), with the lowest temperature value achieved in 1684 when the anomaly is $\sim 4$ sd below mean temperature. Grove and Conterio (1994) also report that in Sicily there was a run of disastrous harvest in the 1690s. In our reconstruction, the mean temperature of the winter of 1683-1684 was estimated with an expected return period of about 1000 years (Figure 4b).

Interpretation of the extraordinary winter 1683-1684. Although the MM was described as a not abnormal period for Italy (Camuffo and Enzi, 1994), some severe climatic subperiods occurred over Europe in 1670s-1680s, with the advancement of Alpine glaciers, and the movement on the waterways of The Netherlands halted by ice in 1679 and ice fair being held on the River Thames (London) in January-February 1684 (Childs, 1982). The exceptional cold winter of 1683-1684 froze the ground in parts of southern England downwards to a depth of $>1 \mathrm{~m}$, while ice formed a $5 \mathrm{~km}$ belt along the English Channel coast. The length of winter frosts was much longer and the depths of snow cover much higher than in the twentieth century - up to 112 days at Zurich, Switzerland (Fagan, 2001). Although this winter was also hard in southern Europe (Beniston, 1994), only few predictors can explain this event in the Mediterranean area (Xoplaki et al., 2001). Thus, we selected winter $1683-1684$ to verify if the reconstructed temperatures show sufficient coherence with the historical and recent documentary climate information that would justify the 

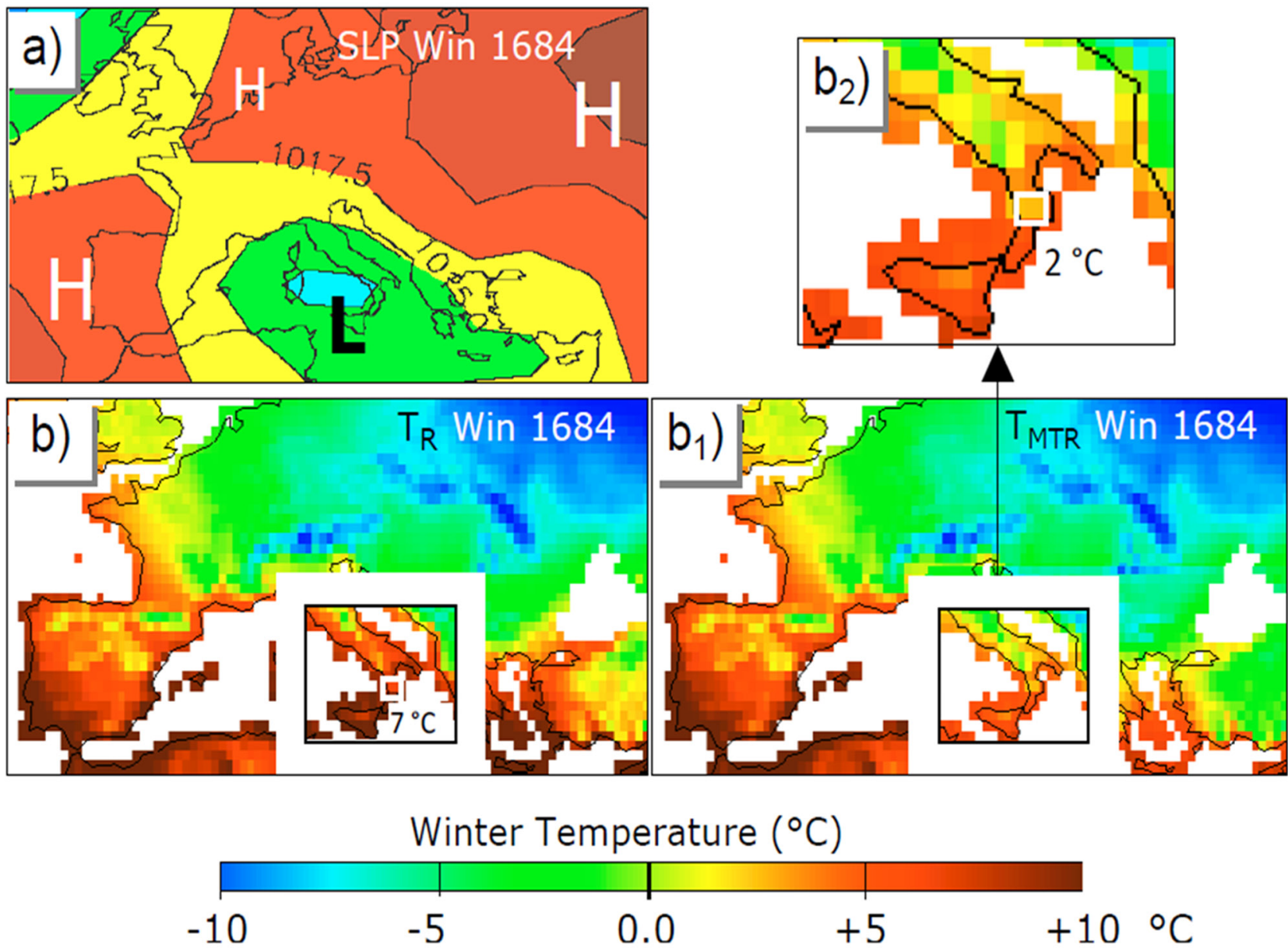

Figure 5. (a) Wintertime average of European sea level pressure (SLP) in 1683-1684 (Win I684), from Luterbacher et al. (2002). (b) The respective regional temperatures $\left(T_{R}\right)$, from Luterbacher et al. (2004). ( $\left.b_{1}\right)$ As in (b) but adjusted to the arrangement proposed in this work $\left(T_{M T R}\right) .\left(b_{2}\right)$ Zoom on the central Mediterranean Sub-regional Area, delimited by big bounding boxes in $(b)$ and $\left(b_{1}\right)$. Smaller boxes in (b) and $\left(b_{2}\right)$ indicate the location of a reference pixel ( $\sim 50 \mathrm{~km}$ resolution)

reconstrution of winter temperatures here proposed for the central Mediteranean subregional area.

The sea level pressure (SLP) pattern (Figure 5a) shows that in 1683-1684, the winter season was characterized by a strong anticyclone stretching from Russia towards Norway and a deep low pressure over the southern Tyrrhenian Sea, thus attracting continuous and extremely cold air masses from the eastern part of the continent. However, this cold adevction is not completely explained in the respective regional temperature from large-scale reconstruction (Figure 5b).

Russian continental areas must have achieved in those years, between 1645 and 1715, the maximum snow depth values (Mackay, 2007). This may have led neighbouring western European areas to a good reservoir of cold. Snow variation over central European Russia and western-central Siberia is indeed associated with a well-known sea surface temperatures anomaly pattern over the Atlantic (Ye, 2001). Thus, it is unsurprising to find chronicles referring to an extraordinary winter in 1684, such as those published in Moio and Susanna Manuscript for Catanzaro site ( $38^{\circ} 54^{\prime}$ North, $16^{\circ} 36^{\prime}$ East, bounded pixel of graphs $b$ and $b_{2}$ of Figure 5) in southern Italy (our translation by Ferrari, 1977):

In the year 1684, the winter was horrific, almost always covered by snows and continuous and large ices, being able to freeze rivers. All citrus trees perished, resulting in a mediocre vintage.
This chronicle should mark an unquestionable point of checking on the temperatures occurred in the winter 1683-1684 in the peninsular Italian region (TASI $=-4$, that is 'freezing' in each of the three winter months, Figure $3 b$ ), with a seasonal average value a few degrees above zero, and yet lower in the remaining part of Italy in the north of Catanzaro (Figure $5 b_{1}$ ).

The seasonal temperature here reconstructed by the (MTR) model (Eq. 1) was equal on average to $\sim 3.5^{\circ} \mathrm{C}$ over the area of Figure $5 b_{2}$. The temperature patterns of Figure $5 b_{1}$ (with zoom in Figure $5 b_{2}$ ) was estimated by correcting the gridded reconstructed results so that the new values depend on a linearly increasing error gradient, from about $0^{\circ} \mathrm{C}$ in the north (roughly centred over the Alpine region and the Po Valley, where the estimates by Luterbacher et al., 2004, are based on a finer resolution of multiproxy and instrumental data) up to $4^{\circ}$ in the south of Italy (centred around Catanzaro), where the average temperature for winter was constrained to the seasonal-mean reconstructed temperatures by Eq. (1). Considering the simplified character of this correction, changes in the atmospheric circulation (Figure 5a) are seen to be remarkably well reflected in the temperature patterns across Italy (Figure $5 b_{1}$ ). On the contrary, the regional reconstruction (Figure $5 b$ ) estimated a winter mean temperature above $6^{\circ} \mathrm{C}$, less reconcilable with the chronicles' description. The difference between the two reconstructions is even larger in the area around Catanzaro $\left(7^{\circ} \mathrm{C}\right.$ against $2^{\circ} \mathrm{C}$, Figure 5, graphs $\mathrm{b}$ and $\mathrm{b}_{2}$, respectively). The corrected patterns of Figure $5 b_{1}$ also disclose winter temperatures around 


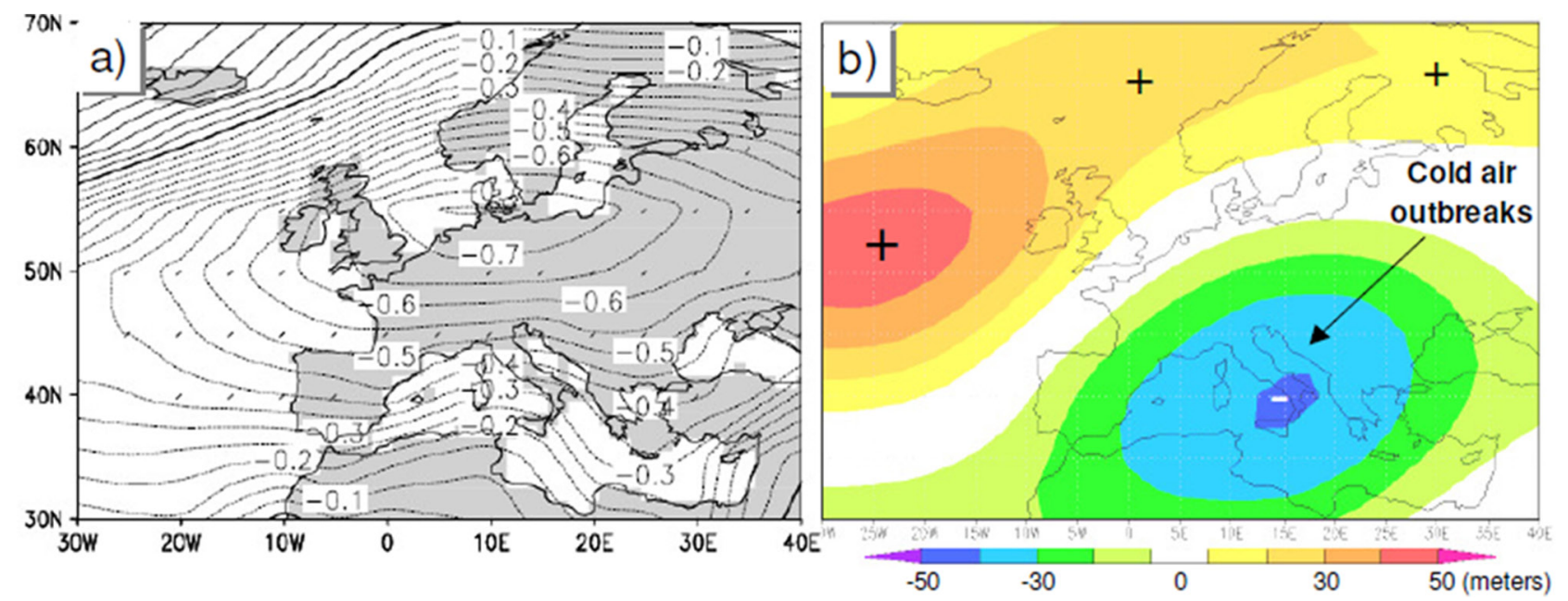

Figure 6. (a) Correlation pattern between sea level pressure (Luterbacher et al., 2002) and solar activity (Lean et al., 1995) during 1659-1997 (supplied by Lohmann et al., 2004). Correlations exceed the 0.90 confidence level and a bold line marks the transition zone between negative and positive correlations (Lohmann et al., 2004). (b) Wintertime geopotential anomalies (meters) at $500 \mathrm{hP}$ during the Maunder minimum relative to 1961-1990 across Europe. The map in (b) was drawn by subtracting, cell by cell, the mean geopotential in the MM and the longterm average for 1961-1990, and arranged using the web-based Climate Explorer of the Royal Netherlands Meteorological Institute (van Oldenborgh and Burgers, 2005), via web-GIS (http://climexp.knmi.nl)

$0^{\circ} \mathrm{C}$ in the internal areas of central Italy, where extreme events (such as frozen rivers) may have occurred over a greater number of days than in southern areas.

Variations in solar activity seem to be a plausible source of forcing phenomena at high latitudes of both hemispheres, but the physical nature of this cyclicity still remains unclear (e.g. Raspopov et al., 2004). In particular, the mechanisms by which the solar signal might be amplified remain uncertain (Haigh, 2001). With focus on rainfall regime in southern Iberia, some authors (Alcoforado et al., 2000; Barriendos, 1997; Rodrigo et al., 2000) concluded that solar activity is unlikely to be the cause of climatic changes. Lockwood (2010) provided new evidences on the relationship between solar changes, but uncertainties are still a real problem because of lack of homogeneity in long data sets. Based on our reconstruction, we can affirm that the Maunder minimum, which was a prolonged episode of low solar activity, coincided with more severe winters occurred not only in the UK and continental Europe (Lockwood et al., 2010) but also in the central Mediterranean area. However, solar activity is supposed to have affected also longer periods, as the map of Figure $6 \mathrm{a}$ suggests for 1659-1997. The correlation map between the solar activity and SLP (Lohmann et al., 2004, after Lean et al., 1995 and Luterbacher et al., 2002) shows in fact that a coherent largescale annular pattern is established. This generates a circulation where low values of solar radiative forcing tend to be associated with easterly and northerly flows over parts of the continental Europe. Negative correlations, centred in the Scandinavian-German borderlands with a decreasing gradient over the whole Mediterranean, also suggest that a blocking of the circulation in the Atlantic, may lead to climate changes in Europe. The relatively low correlations observed for the Mediterranean area (of about -0.2 to -0.4 ) can be explained by subregional factors, such as the local cyclogenesis (e.g. Lionello et al., 2006) that may alter the large-scale correlation.

Since the SLP during the late MM winter was significantly higher in northen Europe but below normal over the central Mediterranean, more frequent blocking situations were connected with cold air outbreaks towards central and southern Europe (Figure 6b). The sign of anomalies during the studied period indicates the prevalence of low or high pressure. In such context, negative anomalies over central Mediterranean area would indicate northeasterly or easterly circulation (zonal circulation), while positive anomalies would indicate prevailing meridional circulation. Luterbacher et al. (1999) suggested, for mid-nineteenth century, that the circulation over the eastern North Atlantic at sea level was temporally decoupled from the continental flow. These results confirm that also during other cold periods of the past than the MM the atmospheric circulations responsible of extreme phenomena over central and eastern Mediterranean were temporally decoupled from the Atlantic airflow (see also Diodato, 2007).

\section{Concluding remarks}

Extreme low temperatures make the Maunder minimum an outstanding climatic period. Based on our reconstruction and some consistency of the empirical evidence, high-resolution wintertime temperatures show for Mediterranean Sub-regional Area a coldest climate $\left(\sim 3^{\circ} \mathrm{C}\right.$ in $\left.1683-1684\right)$ than that represented by coarser reconstruction of European temperatures during the LIA period $\left(\sim 6^{\circ} \mathrm{C}\right.$ in the same winter of $\left.1683-1684\right)$. Averaged subregionally temperatures are therefore important to reproduce signals of climate variability that are hidden in large-scale time series, and this points to the importance of subregional reconstructions of historical climate.

Another indication is that a number of unusually warm or cold intervals can be seen in most proxy records of temperature. For the years of the Maunder minimum, temporal high-resolution reconstructions disclosed indeed key climatic features, such as locally very mild or cold winters that may be masked in a hemispheric or continental reconstruction. European climate is unique in many regards, and as such, it poses a unique challenge for climate prediction (Woollings, 2010). Also recently, in spite of the continuing warmth of the late twentieth century, the European regions have reached extraordinary records. In 2009/2010, they were characterized by snow and cold winter anomalies (Cattiaux et al., 2010; Seager et al., 2010), followed by a very warm summer in western Russia (http://www.giss.nasa.gov/ research/news/20100930). The cold anomaly in central and northern Europe has continued and strengthened in the early part of the winter of 2010-2011 (http://data.giss.nasa.gov/gistemp/ 2010 november). What we like to remark here is that also in a warming planet the occurrence of extreme and/or prolonged 
cold episodes can incidentally be induced by unpredictable forcing from the atmospheric circulation.

\section{Acknowledgements}

The Authors acknowledge the helpful observations and suggestions of Fernando Rodrigo from the University of Almería (Spain) and two anonymous referees for improving the manuscript. They are also grateful to Anna Mancini for editing the English language.

\section{Funding}

This research received no specific grant from any funding agency in the public, commercial, or not-for-profit sectors.

\section{References}

Alcoforado M-J, de Fatima Nunes M, Garcia JC and Taborda JP (2000) Temperature and precipitation reconstruction in southern Portugal during the late Maunder Minimum (AD 1675-1715). The Holocene 10: 333-340.

Barriendos M (1997) Climatic variations in the Iberian Peninsula during the late Maunder Minimum (AD 1675-1715): An analysis of data from rogation ceremonies. The Holocene 7: 105-111.

Beniston M (1994) Mountain Environments in Changing Climates. London: Routledge.

Bhatnagar A, Jain K and Tripathy SC (2002) Variation of solar irradiance and mode frequencies during Maunder minimum. Astrophysics and Space Science 281: 761-764.

Bond G, Kromer B, Beer J, Muscheler R, Evans MN, Showers W et al. (2001) Persistent solar influence on North Atlantic climate during the Holocene. Science 294: 2130-2136.

Bradley RS and Jones PD (1992) Climate since A.D. 1500: Introduction. In: Bradley RS and Jones PD (eds) Climate Since A.D. 1500. London: Routledge, 1-16.

Brázdil R, Pfister C, Wanner H, von Storch H and Luterbacher J (2005) Historical climatology in Europe - The state of the art. Climatic Change 70: $363-430$.

Brewer S, Alleaume S, Guiot J and Nicault A (2007) Historical droughts in Mediterranean regions during the last 500 years: A data/model approach. Climate of the Past 3: 355-366.

Camuffo D (1987) Freezing of the Venetian Lagoon since the 9th century AD in comparison to the climate of Western Europe and England. Climatic Change 10: 43-66.

Camuffo D and Enzi S (1994) The climate of Italy from 1675 to 1715. In: Frenzel B, Pfister C and Glaser B (eds) Climatic Trends and Anomalies in Europe 1675-1715. Paleoclimate Research, Special Issue 8. Stuuugart: Gustav Fisher Verlag, 243-254.

Camuffo D, Bertolin B, Barriendos M, Dominguez F, Cocheo C, Enzi S et al. (2010a) 500-year temperature and precipitation reconstruction in the Mediterranean Basin. Climatic Change 101: 169-199.

Camuffo D, Bertolin B, Jones PD, Cornes R and Garnier E (2010b) The earliest daily barometric pressure readings in Italy: Pisa AD 1657-1658 and Modena AD 1694, and the weather over Europe. The Holocene 20: 337-349.

Cattiaux J, Vautard R, Cassou C, Yiou P, Masson-Delmotte V and Codron F (2010) Winter 2010 in Europe: A cold extreme in a warming climate. Geophysical Research Letters 37: L20704, doi:10.1029/2010GL044613.

Childs J (1982) Armies and Warfare in Europe, 1648-1789. Oxford: Manchster University Press.

Clemente GF and Margottinin C (1991) Sistema EVA: Una biblioteca di dischi 464 ottici per le catastrofi naturali del passato. Prometeo 9: 22-29 (in Italian)

Corradi A (1972) Corradi Alfonso: Annali delle epidemie occorse in Italia dalle prime memorie fino al 1850, five volumes, reprinted by Società medico-chirurgica di Bologna. Bologna: Forni (in Italian).

Derham W (1733-1734) An abstract of the Meteorological Diaries, communicated to the Royal Society, with re-marks upon them, by W. Derham, D. D. Canon of Windsor, F. R. S. [Vide Part III. In Transact. No 433.] Part IV. Philosophical Transactions (1683-1775) 38: 405-412.

Diodato N (2007) Climatic fluctuations in Southern Italy since 17th century: Reconstruction with precipitation records at Benevento. Climatic Change 80: 411-431.

Diodato N, Bellocchi G, Bertolin C and Camuffo D (2010) Multiscale regression model to infer historical temperatures in a central Mediterranean Sub-regional area. Climate of the Past Discussions 6: 2625-2649.
Eddy JA (1976) The Maunder minimum. Science 18: 1189-1202.

Fagan B (2001) The Little Ice Age: How Climate Made History, 1300-1850. New York: Basic Books.

Ferrari U (1977) Giovan Battista Moio, Gregorio Susanna: Diario di quanto successe in Catanzaro dal 1710 al 1769. Chiaravalle Centrale: Edizioni Effe Emme (in Italian).

Grove JM (1988) The Little Ice Age. London: Methuen.

Grove JM (2001) The initiation of the 'Little Ice Age' in regions round the North Atlantic. Climatic Change 48: 53-82.

Grove JM and Conterio A (1994) Climate in the eastern and Central Mediterranean, 1675 to 1715 . In: Frenzel B, Pfister C and Glaser B (eds) Climatic Trends and Anomalies in Europe 1675-1715. Stuttgart: Gustav Fischer, 275-285.

Haigh JD (2001) Climate variability and the influence of the Sun. Science 294: 2109-2111.

Haigh JD (2003) The effects of solar variability on the Earth's climate. Philosophical Transactions of the Royal Society A-Mathematical Physical and Engineering Sciences 361: 95-111.

Jansen E, Overpeck J, Briffa KR, et al. (2007) Palaeoclimate. In: Solomon S, Qin D, Manning M, et al. (eds) Climate Change 2007: The Physical Science Basis; Contribution of Working Group I to the Fourth Assessment Report of the Intergovernmental Panel on Climate Change. Cambridge: Cambridge University Press, 433-497.

Jones PD and Mann ME (2004) Climate over past Millennia. Reviews of Geophysics 42: RG2002, 2003RG000143.

Lamb HH (1982) Climate History and Modern World. London: Methuen.

Lattanzi B (2000) Storia di Foligno, vol. III (1439-1797). Rome: IBN Editore.

Lean J, Beer J and Bradley R (1995) Reconstruction of solar irradiance since 1610: Implications for climate change. Geophysical Research Letters 23: 3195-3198.

Lionello P, Bhend J, Buzzi A, et al. (2006) Cyclones in the Mediterranean region: climatology and effects on the environment. In: Lionello P, Malanotte-Rizzoli P and Boscolo R (eds) Mediterranean Climate Variability. Developments in Earth and Environmental Sciences, Vol. 4. Amsterdam: Elsevier, 325-372.

Lockwood M (2010) Solar change and climate: An update in the light of the current exceptional solar minimum. Proceedings of the Royal Society A-Mathematical Physical and Enginnering Sciences 466: 303-329.

Lockwood M, Harrison RG, Woollings T and Solanki SK (2010) Are cold winters in Europe associated with low solar activity? Environmental Research Letters 5: 024001.

Loehle C (2009) A mathematical analysis of the divergence problem in dendroclimatology. Climatic Change 94: 233-245.

Lohmann G, Rimbu N and Dima M (2004) Climate signature of solar irradiance variations: Analysis of long-term instrumental, historical, and proxy data. International Journal of Climatology 24: 1045-1056.

Luterbacher J, Dietrich D, Xoplaki E, et al. (2004) European seasonal and annual temperature variability, trends and extremes since 1500. Science 303: 1499-1503.

Luterbacher J, Schmutz C, Gyalistras D, et al. (1999) Reconstruction of monthly NAO and ED indices back to AD 1675. Geophysical Research Letters 26: 2745-2748.

Luterbacher J, Xoplaki E, Dietrich D, et al. (2002) Reconstruction of sea level pressure fields over the eastern North Atlantic and Europe back to 1500 . Climate Dynamics 18: 545-561.

Mackay AW (2007) The paleoclimatology of Lake Baikal: A diatom synthesis and prospectus. Earth-Science Reviews 82: 181-215.

Manley G (1974) Central England temperatures: Monthly means 1659 to 1973. Quarterly Journal of the Royal Meteorological Society 100: 389-405.

Nicholls N (2010) Why do we care about past climates? An editorial essay. Wiley Interdisciplinary Reviews: Climate Change 1: 155-158.

Ogilvie AEJ and Jónsson T (2001) Little Ice Age research: A perspective from Iceland. Climatic Change 48: 9-52.

Raspopov OM, Dergachev VA and Kolström T (2004) Periodicity of climate conditions and solar variability derived from dendrochronological and other palaeoclimatic data in high latitudes. Palaeogeography Palaeoclimatology Palaeoecology 209: 127-139.

Rodrigo FS, Esteban-Parra MJ, Pozo-Vázquez D and Castro-Díez Y (2000) Rainfall variability in southern Spain on decadal to centennial time scales. International Journal of Climatology 20: 721-732.

Seager R, Kushnir Y, Nakamura J, et al. (2010) Northern hemisphere winter snow anomalies: ENSO, NAO and the winter of 2009/10. Geophysical Research Letters 37: L14703, doi:10.1029/2010GL043830.

Skinner L (2008) Facing future climate change: Is the past relevant? Philosophical Transactions of the Royal Society A: Mathematical Physical and Engineering Sciences 366: 4627-4645. 
Van Oldenborgh GJ and Burgers G (2005) Searching for decadal variations in ENSO precipitation teleconnections. Geophysical Research Letters 32: L15701, doi:10.1029/2005GL023110.

Visser H, Büntgen U, D'Arrigo R and Petersen AC (2010) Detecting instabilities in tree-ring proxy calibration. Climate of the Past Discussions 6 : 225-255.

Wanner H, Beer J, Bütikofer J, et al. (2009) Mid- to late Holocene climate change: An overview. Quaternary Science Reviews 27: 1791-1828.
Woollings T (2010) Dynamical influences on European climate: An uncertain future. Philosophical Transactions of the Royal Society A: Mathematical Physical and Engineering Sciences 368: 3733-3756.

Xoplaki E, Maheras P and Luterbacher J (2001) Variability of climate in meridional Balkans during the periods $1675-1715$ and $1780-1830$ and its impact on human life. Climatic Change 48: 581-615.

Ye H (2001) Quasi-biennial and quasi-decadal variations in snow accumulation over Northern Eurasia and their connections to the Atlantic and Pacific oceans. Journal of Climate 14: 4573-4584. 